\title{
Küresel Tüketici Kültürü Kavramıyla Birlikte Değişen Pazar Bölümlendirme Yaklaşımları: Uluslararası Pazarlama Literatürüne Bakış*
}

\author{
Ramazan NACAR ${ }^{* * *}$ \\ Nimet URAY ${ }^{* * *}$
}

\section{Özet}

Pazarlama stratejisinin en önemli unsurlarından biri olan pazar bölümlendirme, küreselleşmenin etkisiyle birlikte, uluslararası nitelik kazanmıştır. Ancak ilk zamanlarında daha çok ülke düzeyinde yapılan uluslararası pazar bölümlendirme çalışmaları, pazarlama araştırmacılarının ve uygulayıcılarının birçok ihtiyacına cevap verememeye başlamıştır. Daha sonraları ortaya çıkan tüketici düzeyindeki uluslararası pazar bölümlendirme çalışmaları ise yine ülkelerarası ve kültürlerarası karşılaştırmalara odaklanmıştır. Hâlbuki küreselleşmeyle ve artan teknoloji, ulaşım ve iletişim imkânlarıyla birlikte, küresel çapta tüketici istek ve ihtiyaçları her geçen gün birbirine daha da yaklaşmaktadır. Sonuç olarak ortaya çıkan küresel tüketici kültürü, uluslararası pazar bölümlendirme çalışmalarında da gerek yöntem gerekse içerik açısından önemli değişikliklere yol açmıştır. Bu çalışma pazarlama literatüründe yaşanan söz konusu değişimi değerlendirmekte ve gelecek çalışmalar için öneriler sunmaktadır.

Anahtar Kelimeler: Uluslararası pazar bölümlendirme, ülke ve tüketici bölümlendirmesi, küresel tüketici kültürü

\section{The Role of Global Consumer Culture Concept in the Evolution of Market}

\section{Segmentation: Review of International Marketing Literature}

\section{Abstract}

Market segmentation, one of the most important elements of marketing strategy, has internationalized with the impact of globalization. However, in its early stages, international market

* $\quad$ Bu çalışma İstanbul Teknik Üniversitesi (İTÜ) Bilimsel Araştırma Projeleri (BAP) biriminin Lisansüstü Tezlerini Destekleme Programı Projeleri kapsamında desteklenmiştir. Ayrıca ilk yazar Türkiye Bilimsel ve Teknolojik Araştırma Kurumu (TÜBİTAK) 2211 Yurt İçi Lisansüstü Burs Programı ve TÜBİTAK 2214 Yurt D1şı Doktora Sırası Araştırma Burs Programı kapsamında desteklenmiştir.

** Ar. Gör. Dr., Yalova Üniversitesi, İktisadi ve İdari Bilimler Fakültesi, Uluslararası Ticaret ve Finansman Bölümü, rnacar@yalova.edu.tr

*** Prof. Dr., İstanbul Teknik Üniversitesi, İşletme Fakültesi, İşletme Mühendisliği Bölümü, urayni@itu.edu.tr 
segmentation studies mostly focused on country segmentations, which did not provide enough to marketing academicians and practitioners. Later on, consumer-level international market segmentation studies focused on cross-country and cross-cultural comparisons of consumers. However, globalization along with the facilities of technology, transportation, and communication, needs and wants of consumers converged increasingly. As a result, the new global consumer culture changed the methods and contents of international market segmentation studies. This study reviews this evolution in international market segmentation and provides suggestions for further studies.

Keywords: International market segmentation, country and consumer segmentation, global consumer culture

\section{Giriş}

Artan küreselleşmeyle birlikte firmalar, pazarlama stratejilerini ulusal s1nırlar dışına genişletmeye ve yeniden düzenlemeye yönelmiştir. İş dünyasının her geçen gün küreselleşmesiyle birlikte, uluslararası pazar bölümlendirmenin (UPB) pazarlama içerisindeki önemi de her geçen gün artmaktadır (Steenkamp ve ter Hofstede, 2002). Tüketici pazarlarının uluslararasılaşması, araştırmac1ları uluslararası pazarlardaki tüketicileri uygun, etkili ve etkin bir biçimde gruplandırabilmek için birtakım pazar bölümlendirme stratejileri belirlemeye zorlamıştır (Christodoulides, Michaelidou ve Siamagka, 2013).

İlk olarak 1956 yılında Wendell Smith tarafindan ortaya atılan pazar bölümlendirme kavramı, içerisinde birçok farklılıklar bulunduran pazarın benzer özellikler gösteren alt bölümlere ayrılması olarak tanımlanmaktadır. Pazar bölümlendirme konusu, uluslararası pazarlamada çok yönlü, çok değişkenli ve bu nedenle çok karmaşık bir yapıya sahiptir. Ancak, UPB alanındaki çalışmaların büyük bir kısmı ülkelerin gruplandırılmasına, diğer bir kısmı hedeflenecek tüketicilerin seçimi için yapılması gereken pazar bölümlendirme değişkenlerinin seçimi ve değerlendirmesine odaklanmıştır (Craft, 2004). Tüketim kültürü ve küreselleşmeyle birlikte modern iş dünyası da değişmeye başlamasına rağmen, küresel tüketici kültürü alanında yeterince çalışma yapılmamıştır (Adams, 2011). Tamer Cavusgil, Susan Douglas, Stanley Reid, Franklin Root ve Jan-Benedict Steenkamp gibi uluslararası pazarlamanın önde gelen akademisyenleri UPB alanının yeterince gelişmediğini, hâlbuki başta uluslararası genişleme stratejileri olmak üzere birçok alanda UPB'nin vazgeçilmez öneme sahip olduğunu ifade etmiştir (Papadopoulos ve Martin Martin, 2011).

Teorik ve yöntem olarak gelişim aşamasında olan UPB'nin tam olarak ileri düzeye gelebilmesi için daha çok ilerleme sağlaması gerekmektedir (Bolton ve Myers, 2003). Steenkamp ve ter Hofstede (2002) çalışmalarında UPB alanındaki yayınların 1990 yılından sonra artmaya başladığını ve genel olarak UPB'nin de öneminin arttığını belirtmiştir. Ancak, UPB'nin artan önemi ve küresel dünyadaki gerekliliğine rağmen 1993 y1lında Aulakh ve Katobe bu 
alanda sadece 11 yayın tespit edebilmiştir. Foedermayr ve Diamantopoulos (2008b) ise doğrudan UPB alanında olan 10 deneysel çalışma tespit etmiştir. Malhotra ve Papadopoulos (2007) ise yarıdan fazlası ikincil veri kullanan ve doğrudan UPB ile ilgili olmayıp, UPB'nin alt konu başlıkları olabilecek alanlarda gerçekleştirilmiş, toplam olarak 40'tan az sayıda UPB çalışmasının bulunduğunu belirtmiştir. Söz konusu yazarların yapmış oldukları literatür araştırmasına göre, günümüzde ise bu rakam yaklaşık sadece 70 civarındadır.

Pazarlamanın temel ilgi alanı olan tüketim, üretimin bir fonksiyonudur; sinırları aşan ve küreselleşen üretimle birlikte artık tüketim de küresel bir yapıdadır (Adams, 2011). Günümüzde uluslararası pazarda faaliyet gösteren firmaların karşılaştı̆g 1 en büyük sorun farklı ülkelerdeki tüketicilerin ihtiyaç ve isteklerindeki farklılıkları etkin bir biçimde karşılamaktır. Burada pazar bölümleri sadece coğrafi olarak değil, aynı zamanda da farklı ülkelerde bulunan, ancak benzer ihtiyaç ve isteklere sahip tüketiciler olarak da bir araya getirilebilmektedir (Steenkamp ve ter Hofstede, 2002). Tüketicilerin uluslararasılaşmasının yanı sıra, hızlı teknolojik gelişmeler, coğrafi sınırların ötesindeki tüketicilerin de hedeflenmesini kolaylaştırmış, firmalara önemli firsatlar sunmaya başlamıştır (Craft, 2004). Küreselleşmenin de etkisiyle her geçen gün daha da uluslararasılaşan pazarlama, ülkeler arası farklılıkları dikkate alan bir yapıdan, küresel düzeyde ülkeler ve kültürler arası benzerliklere odaklanan bir anlayışa ve yapıya doğru yönelmeye başlamıştır (Adams, 2011). Bu açıdan da bakıldığında, firmaların uluslararasılaşma faaliyetleri arttıkça, teknolojik gelişmeler, pazarlar arası etkileşimi ve iletişimi sınırsız hale getirdikçe, uluslararası pazarlarda bölümlendirmenin çok daha önemli bir araştırma konusu halini alacağ 1 açıktır.

Nitekim son yıllarda stratejik pazarlama yazınında uluslararası bölümlendirme kavramının önemi giderek artmaktadır (Foedermayr ve Diamantopoulos, 2008a). Bijmolt, Paas ve Vermont'un (2004) önemle ortaya koyduğu gibi, UPB'nin etkili bir biçimde uygulanması, firmaların uluslararası pazar stratejilerini başarılı bir biçimde geliştirmelerine ve uluslararası pazarlardaki farklılıklarla baş edebilmelerinde büyük katkılar sunmaktadır. Pazarlama stratejilerinin temelini oluşturan pazar bölümlendirme, uluslararası pazarlarda faaliyet gösteren firmalar açısından vazgeçilmez ve hayati önemde olup, doğru pazar bölümlerinin oluşturulması, hedeflenmesi, yönetilmesi ve pazarlama stratejilerinin oluşturulmasında da rolü büyüktür (Steenkamp ve ter Hofstede, 2002). Pazar bölümlendirmede ise bölümlendirmede kullanılacak değișkenlerin seçimi, bu alanın en önemli konularından birisi olmuştur.

Bunlara ek olarak, firmaların karşılaştıkları büyük problemlerden birisi de standartlaşma veya uyarlama stratejilerinin uygulanıp uygulanmaması konusundaki ikilemdir. Buna çözüm olarak ise birçok araştırmacı küresel, yerel 
ve karma (hibrit) pazarlama yaklaşımlarını önermektedir (örneğin, Cavusgil ve diğ., 1993; Cavusgil ve Zou, 1994; Douglas ve Wind, 1987; Onkvisit ve Shaw, 1994). Ancak tüm bu sorunların en gerçekçi ve öngörülebilir çözümü pazar bölümlendirme stratejileridir (Souiden, 2002). Ulusal sınırlar ötesinde faaliyet gösteren firmalar açısından ürün geliştirme, konumlandırma ve satış konusunda UPB'nin önemi giderek artmaktadır. Bu anlamda UPB, firmaların uluslararası pazarlardaki muhtemel müşterileri hedeflemesinde ve ulusal s1nırlar ötesinde uygun konumlandırma yapabilmesinde büyük destek sunmaktadır (Steenkamp ve ter Hofstede, 2002).

Bu makale uluslararası pazar bölümlendirmede kullanılan değişkenleri incelemekte ve kültürel faktörlerin bu değişkenler arasında artan önemine işaret etmektedir. Böylelikle uluslararası pazar bölümlendirmesi ve bunda temel olan değişkenlerin kullanımıyla ilgili gelecek görüşleri ve tehlikeler değerlendirilmiştir. Bu amaçla UPB alanında önde gelen çalışmalar değerlendirilmiş ve UPB'nin kavramsal boyutu tartışılmıştır.

\section{Uluslararası Pazar Bölümlendirme (UPB)}

Pazar bölümlendirme kavramı ilk olarak Wendell Smith (1956) tarafindan ortaya atılmıştır. Pazar bölümlendirme, kitlesel pazarlamanın artan ürün rekabetine cevap verememesi nedeniyle kitlesel pazarlamaya bir alternatif olarak sunulmuştur. Smith (1956) ürünlerin pazarın tümünü değil de, aralarında benzerlikler bulunan ve ürüne en uygun olan pazara sunulması durumunda daha büyük başarı elde edilebileceğini belirtmiştir. Bundan sonra da pazar bölümlendirme, pazarlama teorisi ve güncel iş dünyasının en temel ve ana konularından birisi olmuştur. Amerikan Pazarlama Derneği (American Marketing Association-AMA, 2008) pazar bölümlendirmeyi, pazarı benzer ihtiyaçlar taşıyan ve benzer yönde davrananların özelliklerine göre birbirinden farklı daha küçük bölümlere ayırma süreci olarak tanımlamış ve oluşan pazar bölümlerinin ölçülebilir, ulaşılabilir, diğer bölümlerden farklılaştırılabilir, tutarlı ve yeterli büyüklükte olması gerektiğini belirtmiştir.

Genel pazar bölümlendirmenin haricinde ise UPB alanı ayrı bir araştırma alanı olarak gelişmiştir. Son yıllarda, dünyadaki ekonomik ve politik gelişmeler, küresel düzeyde pazarların yakınlaşması ve ülke içi tüketici ihtiyaçlarının daha da parçalı hale gelmesiyle birlikte UPB'nin de önemi giderek artmıştır (ter Hofstede ve diğ., 2002; Foedermayr ve Diamantopoulos, 2008a). UPB ilk olarak Wind ve Douglas'ın 1972 yılındaki çalışmasında ortaya atılmış ve tartış1lmıştır. Bu zamana kadar pazar bölümlendirme sadece yerel pazarlarda çalışılan bir alan olmuştur. Wind ve Douglas (1972) bölümlendirmenin uluslararası pazarlar açısından öneminin, yerel pazarlar için olan öneminden daha 
fazla olduğunu, bunun sebebini ise uluslararası pazarların yerel pazarlardan daha karmaşık olması ve farklılıklar barındırması olarak ifade etmiştir. Ancak bununla birlikte, UPB alanındaki çalışmaların sayısı son derece azdır. Mevcut çalışmaların da büyük kısmı kavramsal niteliktedir, diğer büyük kısmı ise yapılan çalışmaları değerlendirmektedir (Foedermayr ve Diamantopoulos, 2008a). UPB'nin pazarlama performansı üzerindeki etkisine göre, literatürde edindiği yerin son derece sınırlı olduğunu söylemek mümkündür (Craft ve Hassan, 2006).

UPB özellikle küresel pazarda faaliyet gösteren ve küresel stratejiler benimseyen firmalar açısından önem arz etmektedir. Küreselleşmeyle birlikte birçok sektörde ulusal sınırların yeri her geçen gün daha da azalmaktadır (Yip, 1995). Ülkelerin bölgesel işbirlikleri oluşturmaları, açık ve serbest pazar ekonomilerinin artış1, küresel yatırımlar, küresel üretim, ulaşım ve taşımacılık imkanlarının dünya genelinde artışı, tüketicilerin eğitim ve gelir düzeylerindeki artış, satın alma gücü ve yaşam tarzı açısından tüketicilerin birbirlerine yakınlaşması, kentleşme oranlarının artışı, bilgi ve iletişim teknolojilerindeki artışa paralel olarak küresel medyanın, bilgi akışının, para ve işgücü dolaş1minın artması firmaları UPB stratejilerini uygulamaya itmektedir (Hassan ve Katsanis, 1994; Yip, 1995).

Bugüne kadar UPB ile ilgili olarak literatür taraması yapan üç adet çalışma bulunmaktadır. Bunlardan ilki 1997 yılında Walters tarafından, ikincisi Walters'ın çalışmasının genişletilmiş versiyonu olarak Steenkamp ve ter Hofstede (2002) tarafından yapılmıştır. Foedermayr ve Diamantopoulos (2008b) ise doğrudan UPB'yi değil, genel olarak pazar bölümlendirme üzerine bir çalışma yapmıştır. Bunun dışında 2011 yılında International Marketing Review dergisi de hem UPB hem de uluslararası pazar seçimi konularını kapsayan iki özel sayı yayınlamıştır. Bunun dışında UPB alanında kapsamlı bir çalışma bulunmamaktadır.

Uluslararası pazar bölümlendirme alanında en geniş ve kapsamlı çalışma Steenkamp ve ter Hofstede (2002) tarafindan yapılmıştır. Yazarlar bu çalışmalarında UPB alanındaki hem kavramsal hem de yöntemsel konuları incelemeye aldıkları 25 makaleyle sistematik olarak değerlendirmişlerdir. UPB' de kullanılan değişkenler açısından kavramsal konular arasında değişken eşdeğerliliği, bütünleştirmenin düzeyi ve bölümlendirme değişkenin seçimi; araştırma yöntemiyle ilgili konular arasında ölçek eşdeğerliliği, örneklem eşdeğerliliği, bölümlendirme yöntemleri değerlendirilmiştir. Bu çalışmadan önce ise Walters (1997), UPB konusunu Steenkamp ve ter Hofstede'ye (2002) benzer, fakat daha yüzeysel biçimde ele almıştır. Steenkamp ve ter Hofstede (2002) ise bu çalışmayı hem derinleştirmiş hem de zenginleştirmiştir. 


\subsection{UPB'nin Stratejik Önemi}

Uluslararası pazarların yerel pazarlara kıyasla daha karmaşı ve daha yüksek rekabete sahne olmasıyla birlikte, pazar bölümlendirmenin, diğer bir ifadeyle UPB'nin önemi firmalar açısından daha çok artmaktadır (Craft, 2004). Farklı ülkelerdeki benzer özelliklere sahip pazar bölümleriyle birlikte, yerel pazarlardaki farklı pazar bölümlerinin tespit edilmesi de UPB'nin amaçlarındandır (Hassan ve Katsanis, 1991). Böylelikle firmalar, dünya genelinde pazar bölümlerinin farklılıklarını anlayacakları gibi yine pazar bölümlerinin ihtiyaç, değer ve tüketim tarzlarındaki benzerliklerini de kavrayabileceklerdir (ter Hofstede, Steenkamp ve Wedel, 1999; Foedermayr ve Diamantopoulos, 2008a).

UPB, tahmin edilenin aksine karmaşık ve zor bir alandır. Burada UPB ile ilgili verilmesi gereken birçok karar değişkeni bulunmaktadır, bunların başında da UPB'nin sistematik ve etkin yapılması, analiz düzeyi, karar vericinin özellikleri ve benzeri faktörler gelmektedir (Papadopoulos ve Martin Martin, 2011). Post modern çağda artık tüketiciler arasında farkl1l1klar değil, tüketicilerin ortak ve benzer özellikleri, daha büyük önem arz etmekte ve küresel düzeyde tüketicilerin ortak bir grup oluşturmaya doğru gittikleri gözlemlenmektedir (Adams, 2011).

UPB'nin sistematik ve etkin bir biçimde yapılması, firmaların pazarlama performanslarını ve uluslararasılaşma sürecindeki başarılarını etkilemektedir (Papadopoulos ve Martin Martin, 2011). Papadopoulos ve Martin Martin (2011) UPB'yi uluslararası pazar seçimiyle ve pazar giriş stratejileriyle (pazar giriş yöntemi, giriş şekli ve zamanı vb.) birlikte çok daha geniş bir karar verme seti olarak değerlendirmektedir. Ancak bununla birlikte, çok az çalışmanın UPB ile uluslararası pazar seçimini ilişkilendirdiğini belirtmişlerdir. Diğer yandan, UPB'nin birbirinden bağımsız olan ama temel kavram olarak örtüştükleri birçok alan da UPB'yle birlikte gelişimini sürdürmüş ve hali hazırda da gelişmeye devam etmektedir. Bu alanlar ülke risk analizi, uluslararası firsat analizi, çevresel tarama ve doğrudan yatırım yer seçimidir. Buradaki en büyük farklılık da her bir alanın geliştirildiği disiplindir; örneğin, UPB daha çok uluslararası pazarlama alanında ve özellikle KOBİ'ler açısından önem arz ederken, doğrudan yatırım için yer seçimi genel olarak çok uluslu şirketler alanında ve bu tür büyük şirketler açısından önem taşımaktadır.

Foedermayr ve Diamantopoulos (2008a) özel olarak UPB'ye odaklanmamakla birlikte, genel olarak pazar bölümlendirmenin firmalara sağladığı faydaları şu şekilde sıralamıştır: tüketiciler ve pazarlar arasındaki benzerlikler ve farklılıkların tanımlanması, tüketici özelliklerinin ve ihtiyaçlarının daha iyi anlaşılabilmesi, müşteri ilişkileri yönetiminin geliştirilmesi, yeni pazar firsatlarının tanımlanması, pazar geliştirme, standartlaşmadan daha fazla faydala- 
nılması, kaynak kullanımı ve dağıtımının daha iyi yapılması, daha iyi planlama, pazarlama hedeflerinin daha iyi belirlenmesi, ürün geliştirme ve rekabet ortamının daha iyi anlaşılması. Hassan, Craft ve Kortam (2003) ve Hassan ve Craft (2004) UPB'nin birbirinden farklı bazı yaklaşımları olduğunu belirtmiştir. Bunlar; benzer ürünleri talep eden ülkelerin tanımlanması, aynı ürünü talep eden farklı ülkelerdeki farklı pazar bölümlerinin hedeflenmesi, birden fazla veya ülkelerin genelinde var olan pazar bölümlerinin belirlenmesi ve benzer ürünlere talebi olan benzer pazar bölümlerine odaklanılmasıdır.

UPB açısından ülkelerin küreselleşmiş olması veya küreselleşme dereceleri de büyük önem taşımaktadır (Hassan ve Craft, 2004). UPB çalışmalarının yürütülmesiyle ilgili olarak gerek farklı ülkelerden gerekse farklı değişkenlerle ilgili verileri elde etme zorluğu, UPB'nin en önemli kısıtlarından biridir (Papadopoulos ve Martin Martin, 2011).

\subsection{UPB Değişkenleri}

Genel olarak pazar bölümlendirme ve özel olarak da UPB çalışmalarında en önemli konu bölümlendirme değişkenlerinin seçimi olmuştur (Foedermayr ve Diamantopoulos, 2008b). UPB açısından en önemli konuların başında bölümlendirmede kullanılacak değişkenler gelmektedir. Çünkü bölümlendirmenin neye göre ve nasıl yapılacağının yanı sıra ülke düzeyinde mi yoksa tüketici düzeyinde mi yapılacağı, bölümlendirmenin başarısı, vb. birçok faktör açısından belirleyici olan bölümlendirme değişkenleridir. UPB açısından bölümlendirme değişkenleri temel olarak genel ve alan özel (domainspecific) olmak üzere ikiye ayrılmaktadır. Genel bölümlendirme değişkenleri de kendi içerisinde gözlemlenebilen ve gözlemlenemeyen olmak üzere ikiye ayrilmaktadır (Wedel ve Kamakura, 2000; Steenkamp ve ter Hofstede, 2002). Frank ve diğ. (1972), Wedel ve Kamakura (2000), Baker (2003) ve Kotler ve Keller (2006) her bir pazar bölümlendirme değişkeninin ve pazar bölümünün seçiminde değerlendirilmesi gereken altı kriteri tanımlanabilirlik (identifiability), büyüklük/önem (substantiality), ulaşılabilirlik (accessibility), istikrar/ tutarlılık (stability), hedeflenebilir (actionability) ve geri dönüş alabilirlik (responsiveness) olarak tanımlamış ve her bir bölümlendirme değişkenini bu kriterlere göre değerlendirmiştir.

Genel ve gözlemlenebilen değişkenler coğrafi yerler, ekonomik göstergeler, politik özellikler ve demografik özellikler vb. olup daha çok ülke düzeyindeki UPB amacıyla kullanılmaktadır. Bu değişkenlere dayalı pazar bölümleri tanımlanabilir, yeterince büyük ve tutarlı olmakla birlikte, hedeflenebilme ve geri dönüş alabilme açısından son derece yetersizdir (Steenkamp ve ter Hofstede, 2002). Hassan ve Craft (2004) da UPB açısından özellikle ulaşılabilirlik 
ve büyüklük/önem kriterlerinin mühim olduğunu ve bölümlendirme stratejileri açısından da göz önünde bulundurulması gerektiğini belirtmişlerdir.

Diğer yandan genel ve gözlemlenemeyen UPB değişkenleri tüketici değerleri ve yaşam tarzları, alan özel UPB değişkenleri ise marka/ürün pazara nüfuz etme oranları, tutumlar, faydalar, alan özel tutumlar ve bir ürün/markanın kullanımıyla ilgili değişkenleri kapsayıp, daha çok tüketici düzeyindeki UPB çalışmalarında kullanılmaktadır. Tüketici değerleri ve yaşam tarzları, genel ve gözlemlenebilen değişkenlere kıyasla UPB açısından daha fazla başarı sağlamaktadır. Değer-temelli bölümlendirme değişkenleri açısından Kahle'nin (1986) Değerler Listesi, Rokeach'1n (1973) Rokeach Değer Anketi ve Schwartz'in (1992) Schwartz Değer Anketi önemli yer tutmaktadır. Yaşam tarzı-temelli bölümlendirmede ise günlük yaşamdaki etkinlikler, ilgi alanları ve düşünceler (Activities-Interests-Opinions-AIOs) önemli yer tutmaktadır. Ancak, değer-temelli bölümlendirme ile yaşam tarzı-temelli bölümlendirme arasında söz konusu kriterler açısından farklılıklar bulunmaktadır. Örneğin, değer-temelli bölümleri tanımlamak kolayken, yaşam tarzı-temelli bölümleri tanımlamak zordur. Diğer yandan, değer-temelli bölümlere ulaşmak ve onları hedeflemek zorken, yaşam-temelli bölümlere ulaşmak ise nispeten daha kolaydır (Steenkamp ve ter Hofstede, 2002).

Alan özel bölümlendirme değişkenleri ise tanımlanması kolay fakat sosyokültürel çevreyle ilişkisi olmayan bölümler ortaya çıkarabilmektedir. Sosyokültürel çevreden etkilenmedikleri gibi, tüketicinin kendisinden de uzaklaşan bu değişkenler, daha çok firmaların pazarlama kararlarını desteklemek amacına hizmet etmektedir. Bu yönleriyle de diğer bölümlendirme değişkenlerinde olmadığ 1 kadar hedeflenebilir ve geri dönüş alınabilir pazar bölümleri oluşturmaktadırlar (Steenkamp ve ter Hofstede, 2002). Wedel ve Kamakura (2000) ürün-özel ve gözlemlenemeyen değişkenlerin gelecekte daha etkili ve etkin pazar bölümlendirme yapabileceğini belirtmiştir.

Foedermayr ve Diamantopoulos (2008b) ise bölümlendirme değişkenlerini genel olarak makro ve mikro değişkenler olmak üzere ikiye ayırmıştır. $\mathrm{Bu}$ değişkenlerden makro olanlar, pazar bölümleriyle ilgili yeterli ve detaylı bilgi sunamadıkları gibi daha çok ülke düzeyindeki pazar bölümlendirme için kullanılmaktadır. Diğer yandan mikro değişkenler ise, daha çok tüketici düzeyinde pazar bölümlendirme çalışmalarında kullanılmıştır.

UPB çalışmaları daha çok ülke düzeyinde yapılmakla birlikte, bölge ve tüketici düzeyinde veya bunların bir karması olarak da ele alınmıştır (Papadopoulos ve Martin Martin, 2011). Literatür, uluslararası firmaların pazarları ülkelere göre değil, tüketici özelliklerine göre bölümlendirilmesi gerekliliğini dile getirmektedir (Riefler, Diamantopoulos ve Siguaw, 2012). Hassan ve 
Craft'a (2004) göre UPB'nin sadece jeopolitik ve ekonomik faktörler ile sadece yaşam tarzı ve davranışsal değişkenlere dayalı olmaması gerekmektedir. $\mathrm{Bu}$ nedenle, her geçen gün daha teknolojik ve küresel hale gelen pazarlarda birbirine daha da yaklaşan tüketici bölümleriyle birlikte UPB'nin daha karmaşık bir hal alması gerek jeopolitik ve ekonomik faktörler gibi makro değişkenlerin gerekse yaşam tarzı ve davranışsal değişkenler gibi mikro değişkenlerin birlikte kullanılmasını önermektedirler.

Son yıllarda UPB alanı ve çalışmalarına olan ilgiyle birlikte, bu alanın artan önemine rağmen, oluşturulan uluslararası pazar bölümleriyle, bunların oluşturulmasındaki kararların etkinliği ve etkililiğini değerlendiren herhangi bir çalışma yapılmamış olup, bunu değerlendirecek bir ölçek de bulunmamaktadır (Foedermayr ve Diamantopoulos, 2008a). Foedermayr ve Diamantopoulos (2008a) UPB'nin etkinliğini değerlendirmek için bölümlendirme etkinliği (segmentation effectiveness) adında çok boyutlu bir ölçek geliştirmiştir. Ölçeğin boyutları ise hedefleme performans1, konumlandırma performans1, maliyetleri azaltma ve artan çevresel belirsizliklere uyumdur. Foedermayr, Diamantopoulos ve Sichtmann (2009) ise, daha önce kavramsal olarak geliştirilen bölümlendirme etkinliği ölçeğini deneysel olarak test etmiştir.

\subsection{UPB'nin Uygulama Süreci}

UPB çalışmalarının büyük kısmı pazar bölümlerinin tanımlanmasına odaklanmıştır. Ancak, firma içerisindeki UPB süreci ve bunun karar mekanizmaları üzerine pek az çalışma yapılmıştır. Bu nedenle Craft (2004), firmaların UPB stratejilerinin oluşturulması sürecini kapsayan çok aşamalı bir çerçeve önermiştir. UPB açısından temelde iki farklı yaklaşım bulunmaktadır. Bunlardan ilki daha geleneksel olan ve ülkeler arasındaki farklılıklara odaklanan yaklaşım, diğeri ise bir sentez veya karma (hibrit) yapıda olan ve ülkeler arasındaki benzerliklere odaklanan yaklaşımdır (Hassan ve Craft, 2004, 2005; Hassan ve diğ., 2003).

UPB stratejilerinin ve sürecinin kavramsallaştırılması, ilk defa Wind ve Douglas (1981) tarafindan çerçevelenmiştir. Wind ve Douglas (1972) de UPB'nin esas olarak iki aşamalı olarak; önce makro değişkenlere dayalı ülke düzeyinde, daha sonrasında ise mikro değişkenlere dayalı tüketici düzeyinde pazar bölümlendirmenin yapılmasını önermişlerdir. İlk önce ülke düzeyinde, sonrasında tüketici düzeyinde pazar bölümlendirme daha sonraları birçok araştırmacı tarafından da önerilmiştir (örneğin, Kale ve Sudharshan, 1987; Kreutzer, 1988; Steenkamp ve ter Hofstede, 2002; Hassan ve diğ., 2003; Hassan ve Craft, 2004, 2005). Ancak, gerek Wind ve Douglas (1972) gerekse Kale ve Sudharshan (1987) UPB'nin bu iki aşamalı yapısının doğrusal veya hiyerarşik olması 
gerektiğini belirtmişlerdir. Buna karşın, ter Hofstede ve diğ. (1999) ise, gerek makro gerekse mikro değişkenlerin bir arada ve aynı anda kullanılarak UPB yapılmasının pazarı daha etkin bölümlendireceğini ifade etmişler ve bunu test etmişlerdir. Bijmolt ve diğg. (2004) de iki aşamalı olarak, hem ülke düzeyinde hem de tüketici düzeyinde finansal ürünleri kullanma durumuna göre pazar bölümlendirmesi yapmıştır. Ancak Craft (2004), tüm bu çalışmalarda karar sürecinin nasıl olduğunun açıklanmaması ve sonrasında bu pazar bölümlerinin nasıl yönetileceği üzerinde durulmamasını eleştirmiştir. Craft'a (2004) göre, sadece pazar bölümlerinin tanımlanması yeterli değildir. Bu nedenle genel kabul gören iki aşamalı UPB'ye üçüncü aşama olarak pazar bölümü yönetiminde kullanılacak değişken veya düzeyin seçim sürecinin eklenmesini önermiş ve bu üç aşamaya bağlı olarak UPB stratejisinin oluşturulması gerektiğini ifade etmiştir. Craft (2004) araştırmasında firmaların gerek doğrusal biçimde bu üç aşamayı kullanmadığını tespit etmiş, gerekse bu üç aşamanın kullanılmasının UPB stratejilerini desteklediği ve güçlendirdiğini belirlemiştir.

Tablo 1: Uluslararası Pazar Bölümlendirme ve Pazarlama Stratejileri

\begin{tabular}{|c|c|c|c|}
\hline & \multicolumn{3}{|c|}{ Hedeflenen pazar bölümü } \\
\hline $\begin{array}{c}\text { Bölümlendirme } \\
\text { yapılan ülke(ler) }\end{array}$ & $\begin{array}{c}\text { Aynı pazar } \\
\text { bölüm(ü/leri) }\end{array}$ & $\begin{array}{c}\text { Farklı pazar } \\
\text { bölüm(ü/leri) }\end{array}$ & $\begin{array}{c}\text { Tüm pazar } \\
\text { bölümleri }\end{array}$ \\
\hline Aynı ülke & Yerel pazarlama & $\begin{array}{c}\text { Bölümlendirme } \\
\text { pazarlaması }\end{array}$ & $\begin{array}{c}\text { Yerel kitle } \\
\text { pazarlamas1 }\end{array}$ \\
\hline Farklı ülkeler & Küresel pazarlama & $\begin{array}{c}\text { Uluslararası } \\
\text { pazarlama }\end{array}$ & $\begin{array}{c}\text { Uluslararas1 } \\
\text { pazarlama }\end{array}$ \\
\hline Tüm ülkeler & Küresel pazarlama & $\begin{array}{c}\text { Uluslararası } \\
\text { pazarlama }\end{array}$ & $\begin{array}{c}\text { Uluslararası kitle } \\
\text { pazarlaması }\end{array}$ \\
\hline
\end{tabular}

Kaynak: Aurifeille, Quester, Lockshin ve Spawton, 2002

Ülkeler arası ve ülke düzeyinde pazar bölümlendirme yaklaşımları birbirinden tamamen ayrı düşünülmemelidir (ter Hofstede ve diğ. 1999). Küreselleşmeyle birlikte UPB'nin uygulanmasında bazı değişiklikler meydana gelmiştir. Örneğin, daha önce tek bir ülke içinde yapılan veya farklı ülkeleri de kapsayan pazar bölümlendirme çalışmaları, artık tek bir küresel pazarın olduğu ve genel olarak ülke sınırlarının gözetilmediği bir yaklaşımla yapılmaktadır. Dolayısıyla, küreselleşmeyle birlikte değişen UPB, pazarlama stratejilerinde de değişikliklere neden olmuştur (Aurifeille, Quester, Lock- 
shin ve Spawton, 2002) (UPB ve pazarlama stratejilerinin sınıflandırılmas1 için Tablo 1'e bakınız).

UPB çalışmalarında veri toplanmak ve özellikle tüketici düzeyindeki verilere dayalı olarak birden fazla ülkede pazar bölümlendirme çalışması yapmak son derece maliyetli ve zordur (Wedel ve Kamakura, 2000; Steenkamp ve ter Hofstede, 2002). Ancak buna rağmen, son yıllarda, UPB alanındaki çalışmalar daha çok tüketici odaklı ve ürün temelli pazar bölümlendirmesini içermektedir.

\section{2. Ülke Düzeyinde UPB}

UPB'de geleneksel olarak ülke düzeyinde pazar bölümlendirme uygulanmıştır. Bir başka deyişle, benzer özelliklere sahip ülkelerden bir pazar bölümü oluşturulmuştur. $\mathrm{Bu}$ anlayışta her bir ülke bir pazar olarak kabul edilmiştir (Cleveland, Papadopoulos ve Laroche, 2011). Geleneksel olarak UPB çalışmaları daha çok makro düzeyde ve çevresel değişkenlere (coğrafik, politik, ekonomik, kültürel) dayanarak ülkeleri gruplandırmaya çalışmıştır (Souiden, 2002). UPB açısından ülke düzeyinde bölümlendirme çalışmaları tüketici düzeyinde bölümlendirme çalışmalarına göre daha eskiye, Sethi'ye (1971) kadar dayanmaktadır. Sethi (1971) kümeleme analizini kullanarak ülkeleri benzer özelliklerine göre gruplandırmıştır. Bu çalışmalar genel olarak makro düzeyde ve ülkeleri bir bütün olarak ele alan çalışmalardır (Agarwal, 2003).

UPB'nin en temel ve doğal şekli ülke bölümlendirmesi olup, burada her ülke bir pazar bölümünü teşkil etmektedir. Birden fazla yerel pazarda faaliyet göstermek (multi-domestic) olarak nitelendirilen bu yaklaşıma göre, firmalar her bir ülkeyi yerel koşullarına göre tercih etmekte ve bu ülkelerde o ülkeye has olabilecek pazarlama stratejileri uygulayabilmektedir. Her ülkede uygulanan strateji birbirinden farklı olabildiği gibi ülkeler arasında da herhangi bir eşgüdüm söz konusu değildir. Reklam stratejileri, dağıtım yöntemleri, fiyatlandırma stratejileri vb. birçok pazarlama karar değişkenleri ülkeye göre değişkenlik göstermektedir (Jeannet ve Hennessey, 1998).

Ülke temelli UPB çalışmaları genel olarak ülke içindeki tüketicilerin benzer (homojen) olduğunu varsayıp, ülkeler arası benzerliklere odaklanarak ülkeleri gruplandırmakta, dolayısıyla pazarı bölümlendirmektedir (Steenkamp ve ter Hofstede, 2002). Burada UPB daha çok coğrafik bölümlendirmeye dayanmakta ve bazen az olmakla birlikte bölgelerin bölümlendirmesi yapılmaktadır. Coğrafi bölümlendirmeye daha çok Avrupa Birliği ülkeleri, Kuzey ve Güney Amerika ülkeleri arasında yapılmaktadır. Ancak bununla birlikte, ülke ve coğrafi bölge açısından seçilen UPB değişkenlerinin ne pazarlama teorisi ne de yönetimsel açıdan yeterlilikleri ve gereklilikleri yeterince değerlendirilmemektedir (Nachum, 1994). Steenkamp ve ter Hofstede (2002) UPB'nin yapis1 


\section{4 • YALOVA SOSYAL BİLIMLER DERGİSİ}

itibariyle birçok ülkeyi kapsaması gerektiğini, ancak her geçen gün daha farklı ülkelerin çalışmalara konu olmasına rağmen, genelde Kuzey Amerika, Avrupa ve Japonya (Triad) ülkelerine karşı bir eğilim olduğunu belirtmişlerdir.

Ülke düzeyindeki bölümlendirme çalışmaları daha çok ekonomik, politik, coğrafik, demografik ve makro kültürel değişkenleri kullanmışlardır (örneğin, Helsen, Jedidi ve DeSarbo, 1993; Huszagh, Fox ve Day, 1986; Hofstede, 1980; Steenkamp, 2001) (Steenkamp ve ter Hofstede, 2002; Hassan ve Craft, 2005). UPB'nin ilk yıllarında ülkeler bir bütün olarak bölümlendirme düzeyi olarak kullanılmıştır. Bunun en büyük nedeni ise ilk yıllardaki deneyimsizlik ve ülkeler arası verilerin çok az olmasıdır. Ancak bununla birlikte kısa süre içerisinde UPB'nin ülke pazarının özelliklerine değil de, tüketici ve ürünle ilgili olması gerektiği ifade edilmiştir (Papadopoulos ve Martin Martin, 2011). Ayrıca, ülke düzeyindeki bu tür pazar bölümlendirmeleri tüketicilerin davranışsal özelliklerini yansıtmaktan çok uzaktır (Hassan ve Craft, 2005). Steenkamp ve ter Hofstede (2002) inceledikleri 25 makaleden 17'sinin UPB'yi ülke düzeyinde ele almalarını ve daha çok ülke verilerine dayalı UPB yapmalarını, toplanması birincil tüketici verilerinden kolay olan özellikle ülkeler hakkında yayınlanan ikincil veriler ve yayınlardan elde edilen çalışmalara bağlamaktadır. Ancak bununla birlikte, ülke düzeyindeki UPB çalışmaları pazarlama ve yönetim açısından yeterli ve gerekli bilgiyi sunmaktan son derece uzaktırlar (Helsen ve diğ. 1993; Nachum, 1994). Ülke düzeyindeki UPB çalışmaları bu alanda baskın bir biçimde öne çıkmakla birlikte, ülke düzeyindeki pazar bölümlerinin pazarlama ve yönetim açısından kullanılabilirliği ve verimliliği son derece düşüktür (Steenkamp ve ter Hofstede, 2002). Ülke temelinde bölümlendirmede genellikle demografik, sosyo-ekonomik, politik ve kültürel değişkenler ulusal düzeyde incelenmiş ve ülkelerin gruplandırılması buna göre yapılmıştır (Nachum, 1994). Hâlbuki son yıllarda tüketici düzeyinde alan özel değişkenlere (ürünlerin pazar nüfuz oranları) dayalı olarak pazar bölümlendirme çalışmaları da yapılmaktadır (Wedel ve Kamakura, 2000).

Ülke düzeyindeki UPB çalışmalarının en büyük eksikliklerinden birisi, bu çalışmaların daha çok keşifsel nitelikte olmaları ve buna bağlı olarak sonuçlarının genelleştirilebilir olmamalarıdır (Steenkamp ve ter Hofstede, 2002). Helsen ve diğ. (1993) makroekonomik değişkenlere dayalı ülke düzeyindeki pazar bölümlendirmeyle mikro değişkenlere dayalı (ürünlerin pazara nüfuzu) ülke düzeyindeki pazar bölümlendirme çalışmalarına kıyasla daha farklı sonuçlar verdiğini ortaya koymuştur.

Bugüne kadar birçok araştırmacı, ülkeler arası kültürel farkları araştırmış ve ülkelerin kültürel olarak birbirlerinden farkını ortaya koymuştur. Ancak diğer yandan, küresel düzeyde farklı kültürler, farklı ülkeler arasında da olsa benzer ve ortak özelliklere sahip tüketicilerin sayısının her geçen gün arttığını belirten 
çalışmalar yapılmıştır (Adams, 2011). Pazarlamanın temel hedefinin de ülkeler değil, tüketiciler olduğu göz önünde bulundurulduğunda, ülke düzeyindeki pazar bölümlendirme çalışmalarından çok tüketici düzeyindeki çalışmaların daha önemli ve pazarlama açısından daha gerekli olduğu anlaşılacaktır.

Küreselleşmeyle birlikte ülkeye ve kültüre özel değişkenlerin önemi artmakta (örneğin, de Mooij, 2004), UPB çalışmalarında ülke düzeyinde bölümlendirme yapmanın herhangi bir gerekçesi kalmamaktadır (Papadopoulos ve Martin Martin, 2011). Ülkeler arasında farklılıklar olduğu muhakkaktır, ancak ülke düzeyindeki pazar bölümlendirmesiyle koca bir ülke tek bir pazar ele alınmaktadır ki, bir ülke bir bütün olarak pazarlamanın hedefi olmaktan artık çok uzaktır. Örneğin, Çin'e tek bir pazar olarak yaklaşıld1ğında, Çin'deki zengin ve fakir tüketicilerin, Çin'deki ve Amerika'daki zengin tüketicilerin birbirlerine benzediğinden daha çok benzediğini varsaymak çok mantıklı değildir. Elbette ki farklı ülkelerde de olsa, benzer özelliklere sahip tüketicilerin paylaştı̆̆ daha fazla değer, ihtiyaç ve istek bulunmaktadır (Adams, 2011).

Bölümlendirme çalışmalarının ilk yıllarında önceden belirlenen nesnel değişkenlere göre pazar bölümlendirmesinin yapılması esas olmuş, ancak zamanla ülkelerin ekonomik, kültürel, coğrafik ve teknolojik faktörler gibi önceden belirlenen makro değişkenlere göre bölümlendirilmesi artık UPB açısindan yeterli ve uygun görülmemeye başlanmıştır.(Hassan ve Craft, 2004). Artık ülkelerin farklı olduğunu ve bir ülkeyi bir pazar olarak analiz eden çalışmalar, küresel pazar ortamında sınırların anlamını yitirdiği ve küresel tüketicinin doğduğu bir zamanda anlamını yitirmeye başlamıştır. Çünkü artık bu çalışmalar mevcut küresel pazarların ve küresel tüketicilerin gerçeklerini kavramak ve kapsamaktan çok uzaktır (Adams, 2011).

Hassan ve Katsanis (1991) ülke düzeyinde pazar bölümlendirmeyi, makro değişkenlere göre yapılması ve tüketici davranışı değişkenlerini dikkate almamas1, bir ülkenin tümünü benzer olarak değerlendirmesi ve ülke içi farklılıkları göz ardı etmesi ve ülkelerarası benzer pazar bölümlerini göz önüne almaması nedeniyle eleştirmektedir. Ülke düzeyindeki pazar bölümlendirme çalışmaları, tüketici davranışlarını göz ardı etmesi, ülke içerisindeki pazar bölümlerini dikkate almaması ve küresel düzeyde ülkelerarası benzer/aynı pazar bölümlerinin olabileceğini hesaba katamaması nedeniyle eksik görülmektedir (Hassan ve Katsanis, 1994).

\section{Tüketici Düzeyinde UPB}

Günümüze kadar UPB çalışmaları ikincil veri toplamanın da kolaylığıyla daha çok yayınlanmış verilere ve kaynaklara göre yapılmış, çok az çalışma bi- 
reysel tüketicileri kapsayan birincil veri toplamıştır (Cleveland ve diğ., 2011). Örneğin, Steenkamp ve ter Hofstede (2002) inceledikleri 25 makaleden sadece 8'inin UPB açısından bireysel tüketici düzeyinde araştırma yaptığını ve ülkeler arası karşılaştırma yaptığını belirtmiştir. Bunun nedenini de daha çok ülkeler arası tüketici verisinin toplanmasının zorluğu ve maliyetine bağlayan yazarlar, sonuçta uluslararası tüketici pazarlarına ait bölümlendirme çalışmalarının araştırmacıların cesaretini kırdığını ifade etmişlerdir.

Artan küreselleşme ve ortadan kalkmaya başlayan sınırlara rağmen, küresel firmalar hali hazırda tam anlamıyla standartlaşmış tek bir pazarlama stratejisi uygulayamamaktadır. Birçok firmanın da dikkate aldığı gibi dünya genelindeki bazı tüketici grupları aynı ülke içerisindeki tüketicilerden daha fazla benzerlikler gösterebilmekte ve firmaları ülke bazında değil de dünya genelinde benzer tüketicileri hedeflemeye yönlendirmektedir. Sonuçta UPB firmalar açısından tüm bu zorlukları aşmada büyük kolaylıklar sağlamakta ve etkili ve etkin pazar bölümlendirme yapmalarına imkan tanımaktadır (Hassan ve Katsanis, 1994). Tüketicilerin bölümlendirilmesinde herhangi bir bütünleştirme (aggregation) düzeyi kullanılmamakta, tüm dünya genelindeki tüketiciler ele alınarak ve herhangi bir ülke, coğrafya, kültür veya bölge gözetmeksizin dünya genelindeki tüketicilere arasındaki benzerliklere odaklanılarak UPB yapılmaktadır. Tüketicilere dayalı, diğer bir ifadeyle herhangi bir bütünleștirme yapılmadan bireysel tüketicilere dayalı UPB, oluşturulan pazar bölümlerinin özelliklerini ve ihtiyaçlarını tanımlamada ülke düzeyindeki UPB'ye göre oldukça iyi sonuçlar sağlamaktadır (Steenkamp ve ter Hofstede, 2002).

Tüketici düzeyindeki UPB çalışmaları daha çok belli bir ürünün özelliklerinin değerlendirilmesi, tutum, risk alg1s1, marka bağl1lığ1 ve değerleri bölümlendirme değişkenlerini kullanmıştır (örneğin, Moskowitz ve Rabino, 1994; Verhage ve diğ. 1989; Yavas, Verhage ve Green, 1992; ter Hofstede ve diğ., 1999; Kamakura, Novak, Steenkamp ve Verhallen, 1993) (Steenkamp ve ter Hofstede, 2002). Yavas ve diğ. (1992) algilanan risk ve marka sadakatine dayalı olarak farklı ülkelerdeki tüketicilerden oluşan pazar bölümlerini tanımlamıştır. Agarwal (2003) ise ülkeler arası pazar bölümlerini belirleyebilmek, büyüklüklerini ve çeşitli pazarlama karar değişkenlerine tepkilerini tahmin edebilmek amacıyla bir model önerisinde bulunmuşladır. Ter Hofstede ve diğ. (2002) farklı ülkelerdeki pazar bölümlerinin coğrafi bölgelerle birleştirilmesi gerektiğini ifade etmişlerdir. Souiden (2002) bir uyarıcıya dayalı olarak Arap ülkelerindeki otomotiv pazarında UPB yapmıştır. Alan özel UPB değişkenlerine örnek olarak Bruning, Hu ve Hao (2009) tüketicilerin uçuş tercihi ve kararında etkili olan faktörlere (örneğin, fiyat, uçaktaki hizmet, aktarma, vb.) göre bir UPB yapmıştır. Lim ve Lee (2010) ise tüketicilerin teknoloji yenilik- 
çiliği, teknoloji fikir liderliği, dış ağ riski ve teknolojik korkuya dayalı UPB yapmıştır.

Tüketici bölümlendirmesinde en önemli konuların başında değişken eşdeğerliliği gelmektedir. Burada bir ülke için geçerli olan bölümlendirme değişkeninin işlevsel, kavramsal ve sınıfsal olarak eşdeğer olması ve var olabilmesi gerekmektedir. Burada UPB için temel alınan değişkenin farklı ülkeler için eşdeğerliliğinin sağlanamaması, oluşturulan pazar bölümlerinin geçerliliğini ve uygunluğunu tehlikeye atacaktır. Farklı bölümlendirme değişkenleri içerisinde de en çok tutum, ürün özelliklerini değerlendirme ve satın alma davranışı gibi alan özel değişkenlerin eşdeğerliliğinin sağlanması zor bir durumdur, çünkü bu değişkenler daha çok içinde bulundukları sosyo-kültürel çevrenin yapısını yansıtmaktadır. Diğer yandan, genel bölümlendirme değişkenleri ise eşdeğerliliğin sağlanması en kolay olan değişkenler olup, bunun tek istisnası yaşam tarzıdır. Bölümlendirme değişkeni eşdeğerliliği UPB alanındaki çalışmaların büyük bir kısmında gerek sağlanamamış gerekse uygun testlerle test edilmemiştir. Örneğin, yaşam tarzına dayalı bölümlendirmede kullanılan VALS (Values-Attitudes-Life styles) çerçevesinin bazı ülkeler için eşdeğerliliği sağlanamamıştır (Steenkamp ve ter Hofstede, 2002).

Amine ve Smith (2009) mevcut pazar bölümlendirme yöntemlerinin özellikle uluslararası pazarlarda tüketicilerin ortak yönleri bulma ve onları aynı pazar bölümünde değerlendirmesini yetersiz bulmaktadır. Bu durumu da mevcut yöntemlerin daha çok coğrafi ve sosyo-demografik değişkenlere odaklanmasına bağlamaktadır. Hâlbuki post modern düşünceyle, gelişen ve değişen dünyada ortaya çıkan post modern tüketicilerle birlikte, pazar bölümlendirme yöntemlerinin de değişmesi bir zorunluluk halini almıştır. Demografik değişkenlere dayalı tüketici düzeyinde UPB'nin, tüketici pazar bölümleri için pazarlama stratejisinde etkisi çok azdır. Belvaux ve Guibert (2012), UPB yapıldıktan sonra söz konusu pazar bölümlerinin varlığının, özelliklerinin vb. test edilmemesini ve geçerliliğinin ortaya konulmamasını eleştirmektedir. $\mathrm{Bu}$ nedenle oluşturduğu pazar bölümlerinin geçerliliğini ülke düzeyindeki pazar bölümleriyle kıyaslamış ve her bir pazar bölümünde neden sonuç zincirlerine dayalı olarak pazar bölümünün işlevselliğini ortaya koymuştur. Ülke ve tüketici düzeyindeki pazar bölümlerini karşılaştırmasının bir diğer nedeni ise hangisinin daha iyi işlediğini test etmektir. Ancak sonuç olarak birinin diğerine göre daha iyi sonuç verdiği söylenememiştir.

\subsection{Tüketici Düzeyinde Modele Dayalı UPB}

Ülke düzeyinde yapılan UPB çalışmalarındaki bölümlendirme daha çok kümeleme analizine dayanan bir bölümlendirme olup, keşifsel bir yapıya sa- 
hiptir. Bu da yapılan pazar bölümlendirmesinde yöneticilerin karar vermesi açısından bazı karar değişkenlerinin tahmin edilmesini zorlaştırmaktadır. Hâlbuki tüketici düzeyindeki UPB çalı̧̧maları her ne kadar bugüne dek keşifsel alanda kalmış olsalar da, günümüzde modele dayalı ve bölümlendirmenin etkinliği üzerine de UPB çalışmaları yapılmaya başlamıştır (örneğin, Helsen ve diğ. 1993; Kumar ve diğ. 1998; ter Hofstede ve diğ. 1999). Modele dayalı UPB çalışmalarında belirli bir teoriye göre bölümlendirme yapılmakta ve söz konusu teoriye uygun olarak geliştirilen teorik modelin her pazar bölümünde nasıl çalıştığı ve değişkenler arası ilişkiler de teste tabi tutulmaktadır. Böylelikle pazar bölümlerinin yönetsel katkısı ve tahmin gücü de artmaktadır (Steenkamp ve ter Hofstede, 2002). Bunlara ek olarak, UPB açısından farklı yöntemler ve süreçler de kullanılmıştır. Örneğin; Kale ve Sudharshan (1987) farklı ülkelerde benzer özelliklere sahip tüketicilerin oluşturduğu stratejik açıdan eşdeğer pazar bölümlerinin belirlenmesine yönelik olarak mikro bölümlendirmeyi; ter Hofstede ve diğ. (1999) farklı ülkelerdeki benzer tüketicilerin belirlenmesi için neden-sonuç zincirlerine (means-end chain) dayalı bölümlendirmeyi kullanmışlardır. Dickson ve Ginter (1987) pazarlama stratejisinin ve pazar bölümü için tahmin edilmeye çalışlan talep fonksiyonunun pazar bölümünün oluşturulmasında kullanılan değişkene dayalı veya bağlı olması gerektiğini, ancak böylelikle, gerçek pazar bölümlerine ulaşılabileceği ifade etmektedir.

Amine ve Smith (2009) mevcut pazar bölümlendirme varsayımlarının ve yöntemlerinin tüketicilerin post modern karakteristikleri, özellikleri ve gerçeklikleri göz önünde bulundurularak yeniden gözden geçirilmesini ve değiştirilmesini önermekte olup; mevcut pazar bölümlendirme yöntemlerinin küresel tüketiciyi tam olarak tanımlayamadığ 1 ve tüketicilerden uygun pazar bölümleri oluşturamadığ 1 için eleştirmiş ve ne şimdiki ne de gelecekteki küresel tüketici özelliklerini dikkate almaktan uzak olduğunu belirtmiştir. Küresel tüketicileri çok boyutlu, tüketimin daha çok sembolik kısmına odaklanan ve sürekli değişen tüketiciler olarak tanımlayan Amine ve Smith (2009), pazarlamanın post modern bakış açısıyla bu tüketicileri değerlendirebileceği, uygun ürün ve hizmetleri geliştirebileceği ve uygun bölümlendirme değişkenlerini bulabileceğini ve geliştirebileceğini ifade etmiştir.

Tüketici düzeyindeki UPB küresel düzeyde yapılabileceği gibi (örneğin, Hassan ve Katsanis, 1991) önce ülke daha sonra ülkelerarası pazar bölümlendirme olarak iki aşamalı (örneğin, Kale ve Sudharshan, 1987; Kreutzer, 1988, Steenkamp ve ter Hofstede, 2002) olarak da yapılmaktadır (Agarwal, 2003). Ancak, Bijmolt ve diğ. (2004) ile Steenkamp ve ter Hofstede'nin (2002) önerdiklerinin aksine iki aşamalı olarak değil, hem ülke hem de tüketici düzeyinde UPB'yi tek aşamada birleştirmiştir. Aurifeille ve diğ. (2002) 
tüketicilerin bir ürüne (şarap) olan ilgisine dayanarak küresel düzeyde UPB yapmış ve sonuçları ülke düzeyinde yapılan UPB ile karşılaştırmıştır. Sonuç olarak, küresel düzeyde yapılan UPB'nin ülke düzeyine göre yapılan UPB'ye göre daha avantajlı sonuçlar verdiği ve daha tercih edilebilir olduğunu raporlamışlardır. Farklı ülkelerdeki tüketici gruplarının aynı ülkedeki tüketici gruplarından daha çok benzer yönleri olduğunu ortaya koyan ter Hofstede ve diğ. (2002), tüketicilerin bulundukları konumları da (ülke içerisindeki bölgeler) hesaba katan bir UPB modeli önermişler ve test etmişlerdir.

Bolton ve Myers (2003) uluslararası fiyatlandırma stratejilerinin oluşturulmasına katkı sağlayacak şekilde hizmet sektöründe UPB çalışması yapmış ve pazar bölümlerini hem yatay hem de dikey olarak oluşturup sonuçları değerlendirmişlerdir. Agarwal, Malhotra ve Bolton (2010) her ne kadar kültürel değişkenler olmasa da algılanan hizmet kalitesine dayalı bir model önermiş ve bu modeli oluşturduğu ülkelerarası ve kültürlerarası pazar bölümlerinde test etmiştir.

Benzer şekilde, Broderick, Greenley ve Mueller (2007) de modele daya1 olarak davranışsal benzerliği (behavioral homogeneity) ülkelerin içinde ve ülkeler arasında test etmiştir. Tüketici ilgileniminin (consumer involvement) davranışsal benzerliğine dayalı UPB yapılmasının gerekçelerini şu şekilde açıklamışlardır. Öncelikle oluşturulan pazar bölümünün tepkiselliği ve bu değişkenin tüketici karar sürecindeki rolü göz önünde alındığında tüketici ilgisi UPB açısından önemli bir değişkendir. İkincisi, söz konusu değişkenin ölçümü, kültürler ve ülkeler arasında değişmezlik (invariant) özelliğine sahiptir ki bu da uluslararası çalışmalar açısından önemlidir. Üçüncüsü, söz konusu değişken ve bu değişkenin olduğu modelin pazar bölümlerinin davranışı tahmin etme gücü yüksektir. Böylelikle pazar bölümü sadece demografik değişkenlere göre oluşturulmadığından, oluşturulan pazar bölümünün nasıl ve ne yönde davranacağı tahmin edilebilir olmaktadır. Son olarak, gerek ülkeler içerisinde gerekse ülkeler arasında gerçekleştirilen pazar bölümleri tanımlanabilir. Tüm bu özellikleriyle tüketici ilgilenimi değişkeni UPB açısından önemli firsatlar sunmaktadir.

Kamakura ve Novak (1992) ülkeler arası pazar bölümlerinin yerel değer sistemlerindeki benzerliklerin bir ifadesi olduğunu belirtmişlerdir. Tüketicilerin kozmopolitan yönelimlerinin UPB açısından başarılı bir değişken olacağ1nı öne süren Riefler ve diğg. (2012) UPB açısından kullanılmak üzere tüketici kozmopolitizmi adında bir değişken geliştirmişler ve uluslararası pazarları, tüketicilerin kozmopolitan ve yerel eğilimlerine göre bölümlendirmişlerdir. Böylelikle tüketiciler tüketimle ilgili bir değişkene göre bölümlendirilmiş ve tüketici kozmopolitanizmi ve satın alma niyeti arasındaki ilişki incelenebilmiştir. 
Küreselleşen ve giderek daha teknolojik hale gelen pazarlar açısından fark11 bir bölümlendirme yaklaşımı izleyen Christodoulides ve diğ. (2013), elektronik pazarlama alanındaki firmaların stratejilerini belirleyebilmesine yardımcı olmak amacıyla uluslararası pazarlardaki internet kullanıcılarının duygusal durumlarına göre pazar bölümlendirmesi yapmıştır. Günümüzün önemli bir perakende aracı haline gelen interneti, kullanım davranışlarına göre tüketicilerin uluslararası pazarda gruplandırılması ve bu grupların tüketicilerin demografik özellikleri ve bulundukları ülkelere göre kıyaslanması elektronik pazarlama alanında çalışan firmalar açısından önemli bulgular sunmuştur. Shiu ve Dawson (2002) ise İngiltere ve Tayvan arasında hem ülkelerarası hem de ülke içerisindeki internet üzerinden alışveriş yapan tüketicileri bölümlendirmiştir, ancak çalışmanın daha çok demografik değişkenlere dayalı olması araştırma sonuçlarının UPB açısından stratejik sonuçlar içermesini kısıtlamıştır. Bu eksikliği, Brengman ve diğ. (2005) gidermiş ve daha önce literatürde yer alan internet kullanıcılarının yaşam tarzları ölçeğine göre UPB çalışması yapmıştır. Dolayısıyla ülke düzeyine kıyasla tüketici düzeyinde olan UPB çalışmaları daha etkin ve etkili sonuçlar üretmişlerdir. Ancak, yine de sadece pazar bölümlerinin tanımlanmasının ötesinde, tüketici düzeyindeki UPB çalışmalarının bir modelle ilişkili olarak pazar bölümlerinin davranışları ve tutumlarını da tahmin etmesi pazarlama açısından büyük avantajlar sunmaktadır. Buna, küreselleşmesinin de etkisiyle dünya genelinde var olmaya başlayan küresel tüketici kültürü de eklenince, UPB çalışmalarının gerek tüketici düzeyinde gerekse model temelli olmasının önemi giderek artmaktadır. Bir sonraki bölüm küresel tüketici kültürü ve ilgili değişkenleri incelemektedir.

\subsection{Küresel Düzeyde Tüketici Davranışlarının Yakınlaşması}

Levitt'ten (1983) günümüze kadar birçok çalışma iletişim, ulaşım, teknoloji vb. alanlardaki gelişmelerin küreselleşmeyi tetiklediğini ve yeni yaşam tarzları ve sosyal kimlikler oluşmaya başladığını dile getirmişlerdir (örneğin, Sheth ve Parvatiyar, 2001). İlk olarak Levitt (1983) tarafindan dile getirilen bu fikirlerde bilgi değişiminin artması ve küresel ekonominin etkisiyle tüketici istek ve taleplerinin de benzemeye ve yakınlaşmaya başladığ 1 ifade edilmiştir. Firat (1997) küreselleşmeyi pazarlama açısından yaşam tarzlarının, ürünlerin, tüketim tarzlarının ve kültürel deneyimlerin zengin-fakir tüm ülkelerdeki görüntüsü olarak tanımlamıştır. Böylelikle küreselleşme küresel pazar bölümlerinin varlığıyla yakından ilişkili olarak görülmüştür (Adams, 2011). Levitt (1983) ve Yip (1995) küresel düzeyde tüketici davranışlarının yakınlaşmasının araştırılması ve test edilmesinin gerekliliğine vurgu yapmıştır. 
Çokuluslu firmaların artışı, küresel sermaye hareketlerinin artışı ve küresel tüketimin benzerliğinin artmasıyla birlikte küresel kültür de yaygınlaşmaya başlamış (Ger ve Belk, 1996) ve kültürel değerlerin, ülkeler arasında yakınlaşmasina neden olmuştur (Agarwal ve diğ., 2010). Hassan ve diğ. (2003) 21. yüzyılla birlikte markaların ve ürünlerin küresel pazarda satılıyor olmasının yeni bir tüketici türü olarak küresel tüketicileri ortaya çıkardığııı ifade etmektedir. Dünya genelinde tüketici bölümlerinin kültürel ve ulusal sınırları aşarak birbirlerine daha da yaklaştı̆̆ını belirten geniş ölçüde ipucu bulunmaktadır (Hassan ve Craft, 2004). Küresel anlamda küresel tüketicilerin varlığını ilk araştıran çalışmalardan bir tanesi Hassan ve Katsanis'in (1991) küresel elitler ve gençleri araştırdıkları çalışmadır. Alden, Steenkamp ve Batra (1999) ise farklı ülkelerdeki küresel, yerel ve yabancı tüketici kültürlerindeki kültürel sembollerin yapısını incelemiştir. Steenkamp, Batra ve Alden (2003) küresel ölçekte özellikle markalara dayalı olarak bireylerin ihtiyaçlarının ve isteklerinin birbirlerine giderek yaklaştığını ve benzediğini ifade etmişlerdir. $\mathrm{Bu}$ durum, küresel markaların nasıl ve neden başarılı olduklarının da bir nedenidir. Agarwal ve diğ. (2010) UPB'nin ülkeler ve kültürler arasında ve içinde davranışsal benzerlikleri ve farklılıkları yakalaması gerektiğini ifade etmişler ve hizmet sektöründe kültürlerarası (yatay pazar bölümleri) ve ülkelerarası (dikey pazar bölümleri) pazar bölümlendirmesi yapmışlardır. Küresel tüketici kültürü ve küresel tüketicilerin ortaya çıkıyor olmasından hareketle Ko ve diğ. (2007) ihtiyaçları, istekleri ve satın aldıkları markaları her geçen gün birbirine daha çok yakınlaşan tüketicilerin yaşam tarzlarına dayalı olarak moda sektöründe kadın tüketiciler için bir UPB yapmış; küresel reklamlar ve modaya dayalı yaşam tarzının markaya ve reklama karşı tutum ile satın alma niyetine etkisini oluşturdukları pazar bölümleri içerisinde test etmiştir.

Kültürlerin ve değerlerin birbirine yakınlaşıyor olması küresel pazar bölümlerinin varlığını desteklemekte ve küresel pazarlama stratejilerinin ülkeler açısından daha benzer olmasını sağlamaktadır (Agarwal ve diğ., 2010). Tüketicilerin özellikleri ve yaşam deneyimleri hızla değişmekte ve birbirlerine daha fazla yakınlaşmaktadır. Yeni teknolojiler tüketicilere öğrenmenin, iletişimin, iş yapmanın, eğlenmenin ve hayatlarını yönetmenin farklı yollarını sunmakta, diğer taraftan da hiç beklenmedik bir şekilde tüm tüketicileri birbirlerine daha çok benzetmektedir. Bu nedenle tüketiciler ve tüketim davranışlarıyla ilgili post modern bakış açısında tüketiciler karmaşık, çok boyutlu ve sürekli değişen bir yapıda görülmektedir ki mevcut pazar bölümlendirme yöntemleri tüketicilerin bu yeni tanımını kaçırmaktadır. Bu, mevcut pazar bölümlendirme yöntemlerinin tamamen ortadan kaldırılması anlamına gelmediği gibi onların farklı yöntemlerle değiştirilmesini de öngörmemektedir. Esas konu pazarı bölümlendirirken, post modern tüketici özelliklerinin dikkate alınmasıdır (Ami- 
ne ve Smith, 2009). Her ne kadar tüketiciler ve tüketici kültürleri birbirlerine yaklaşsa da bu daha çok batı kültürüne doğru ve onun çevresinde gerçekleşmektedir (Adams, 2011).

Tüketiciler ve pazarlar arasındaki etkileşimin artmasıyla birlikte küreselleşmenin etkileri daha da yoğunlaşmış, araştırmacıları yatay veya küresel pazar bölümlendirmesi yapmaya zorlamıştır. Bu yaklaşımdaki temel amaç ülke sınırlarını göz önüne almadan, tüm dünyayı tek bir pazarmış gibi ele almak ve tüm tüketicilere dayalı olarak pazar bölümlendirmesi yapmaktır (Bolton ve Myers, 2003). Hassan ve Craft (2005) küresel pazar bölümlendirmesi yaparken kullanılan dört yaklaşımı şu şekilde sıralamıştır: farklı ülkelerdeki benzer taleplere sahip olan tüketici bölümlerini keşfetme, aynı ürün için farklı ülkelerdeki farklı pazar bölümlerini hedefleme, birçok ülkede var olan pazar bölümlerini tanımlama ve aynı ürüne talebi olan aynı pazar bölümlerine odaklanma.

\subsection{Küresel Tüketici Kültürü ile İlişkili Değişkenler}

Küreselleşme ve pazarlama araçlarının getirdiği kültürel yakınlaşmayla birlikte, küresel pazar bölümleri ortaya çıkmış ve UPB açısından küresel kültürle ilgili faktörler öne çıkmaya başlamıştır. Kültürel bölümlendirme değişkenleri UPB açısından önemli olmakla birlikte, bu değişkenlerin farklı ülkelerdeki tüketicilerin farklılaşan özelliklerine değil, benzeyen özelliklerine odaklanması UPB açısından daha büyük önem taşımaktadır. Bu nedenle son zamanlarda önemi artan küresel tüketici kültürüne dayalı ve küresel kültürle ilişkili yeni bölümlendirme değişkenlerinin geliştirilmesi ve UPB amacıyla kullanılması gerekmektedir. Bu durum UPB'nin gerek daha doğru pazar bölümleri oluşturmasını sağlayacak gerekse başarısını arttıracaktır. Hassan ve Craft'a (2004) göre küresel pazarda tüm ülkelerde geçerli olabilecek pazar bölümlendirme değişkenlerinin olması veya geliştirilmesi, oluşturulan pazar bölümlerine dayalı pazarlama stratejilerini daha güçlü kılacaktır.

Küresel ölçekte tüketicilerin birbirlerine daha çok benzemesiyle ve pazarların giderek daha çok küreselleşmesiyle birlikte farklı ülkelerdeki tüketiciler arasındaki benzerlikler artarken, aynı ülkedeki tüketiciler arasındaki farklılıklar da artmaktadır. Tüm bu nedenlerden dolayı Cleveland ve Laroche (2007) tüketicilerin küresel tüketici kültürüne uyum değişkenini geliştirmiş ve buna dayalı olarak küresel pazarların bölümlendirilmesi gerektiğini önermiştir. Ancak önemi giderek artan kültürel değişkenlere göre pazar bölümlendirmeye rağmen, geliştirilen bu değişken literatürde yeterli sayıda çalışma tarafından kullanılmamıştır. Carpenter ve diğ. (2012) tüketicilerin küresel tüketici kültürüne açık olmasını, tek ülkede (ABD) ölçmüş ve bu değişkenin yaş kuşak- 
larına göre önemli bir pazar bölümlendirme aracı olabileceğini belirtmiştir. Her ne kadar farklı ülkelerde test edilmese de küresel tüketici kültürüne uyum değişkenini küresel tüketicilerin pazar bölümlendirilmesinde kullanılabileceğini belirtmişlerdir.

Pazarlama çalışmalarının daha çok geçici konular üzerinde yapılması, önemlerinin daha kısa zamanda yok olmasına neden olmaktadır. Hâlbuki örneğin, tüketiciler arası farklıklara değil, benzerliklere odaklanılması, pazarlama çalışmalarının etkisini ve değerini daha da arttıracaktır (Adams, 2011). Küresel kültürün etkisi altında kültürel grupların artıyor olması, ülkeler arasındaki yatay küresel pazar bölümlerinin varlığını daha çok desteklemektedir (Agarwal ve diğ., 2010). Örneğin, Ko ve diğ. (2012) tüketicilerin yaşam tarzlarına ve spor giyim davranışlarına bağlı olarak söz konusu sektörde küresel pazar bölümlendirmesi yapmıştır. Sonuçta, küresel pazarlama stratejilerini ve küresel tüketici kültürünün artan varlığını destekleyen sonuçlar elde etmişlerdir. Arnett (2002) küresel kimliği tüketicilerin kendilerini küresel kültüre ait hissetmeleri, küresel değerleri, inançları, yaşam tarzını ve tüketim tarzını paylaşması olarak tanımlamıştır. UPB açısından ise küresel kimlik, ülkeler arasındaki küresel tüketicilerin belirlenmesi ve buna dayalı olarak pazar bölümlerinin oluşturulması açısından büyük bir fırsat sunmaktadır. Agarwal ve diğ. (2010) dünya genelinde kültürlerin yakınlaşması ve sonucunda küresel kültürün ortaya çıkmasıyla birlikte kültür temelli ve ülkelerarasında var olabilecek küresel pazar bölümlerinin oluşturulmasının ülke temelli pazar bölümlerinden daha başarılı olacağını ortaya koymuş ve bunu geliştirmiş olduğu model temelli araştırmasında test etmiştir. Cleveland ve diğ. (2011) etnik kimlik ve kozmopolitanizm değişkenlerine dayalı olarak bir UPB modeli önermiştir.

Amine ve Smith (2009) de dünya genelinde sadece bir tek pazar bölümünün olup olamayacağını sorgulamış ve olması durumunda, bu tüketici grubunun geleneksel tüketicilerden tutum, ilgi, fikir, düşünce ve davranış açısından farklı olacağını ifade etmiştir. Ülke kültürünün veya kültürel çevrenin benzer veya karmaşık yapıda olmasının da pazar bölümlendirmeyi etkileyen bir unsur olduğunu ifade etmişlerdir (Cannon ve Yaprak, 2011). Erez ve Gati (2004) kültürün çok katmanlı olduğunu öne sürmüş ve ilk önce küresel kültürün makro düzeydeki ulusal kültürü, daha sonra meso düzeydeki örgütsel veya grup kültürünü ve son olarak da bireysel düzeydeki bireysel kültürü şekillendirdiğini ve kendisinin bu değişimden etkilendiğini ifade etmiştir. Burada, küreselden bireysele, değerler ve kültürler değişerek aktarılırken, her düzeyde tamamen benzerlikler değil, aynı zamanda farklılıklar da oluşmaktadır. $\mathrm{Bu}$ da kültürel değişkenlerle küresel düzeyde UPB'yi zorunlu kılmaktadır. Çok az çalışma küresel pazar bölümlerinin varlığından bahsetmiş ve bu pazar bölümlerini oluşturmuştur. Küresel tüketiciler arasında da küresel elitler ve genç 
kesim en başta gelmektedir. Hâlbuki UPB sınırları aşan ve küresel pazar bölümlerini tespit etmedeki işlevini tam olarak kullanmamaktadır (Belvaux ve Guibert, 2012).

Genel ve gözlemlenebilen bölümlendirme değişkenlerinin tanımlanabilirliği, ulaşılabilirliği ve tutarlılığ göre daha yüksek olmakla birlikte, genel ve gözlemlenebilen bölümlendirme değişkenlerinin de hedeflenebilir olmama ve geri dönüş almanın zor olması problemleri bulunmaktadır, bu açıdan, alan özel bölümlendirme değişkenleri daha başarılıdır. Söz konusu bu iki nedenden dolayı, genel ve gözlemlenemeyen bölümlendirme değişkenleri Wedel ve Kamakura (2000) tarafından geliştirilen bölümlendirme değişkenlerinin seçimi kriterlerinin hemen hepsinde ortalarda yer almakta ve bir bütün olarak hem genel ve gözlemlenebilen hem de alan özel değişkenlere göre daha çok tercih edilmektedir. Ancak bu değişkenlerin de diğerlerinden farklı olarak değişken eşdeğerliliği sorunu bulunmaktadır ki, bu oluşturulan bölümlerin geçerliliğini ve uygunluğunu tehlikeye atmaktadır. Bir yanda bölümlendirme değişkenlerinin seçimi kriterlerini sağlama, diğer yanda değişken eşdeğerliliğin sağlanması, Steenkamp ve ter Hofstede'ye (2002) göre UPB'nin en büyük ikilemi ve sorunu olup ve iki aşamalı UPB yöntemi bu sorunu engelleyecektir. Bu yönteme göre, öncelikle benzer ülkeler gruplandırılacak, ikinci aşamada ise daha çok alan özel değişkenlere bağlı olarak UPB yapılacaktır. Steenkamp ve ter Hofstede (2002) tarafından önerilmesine karşın makro değişkenlere dayalı ülke düzeyinde bölümlendirme, ardından mikro değişkenlere dayalı tüketici düzeyinde pazar bölümlendirmesi, daha önce de birçok araştırmada kullanılmıştır (örneğin, Yavas, Bronislaw ve Green, 1992; ter Hofstede ve diğ., 2002; Agarwal, 2003). Yine Hassan ve diğ., (2003) ve Hassan ve Craft (2012) karma/ bütünleşik pazar bölümlendirme yaklaşımı olarak hem makro hem de mikro değişkenlere dayalı pazar bölümlendirmesinin hedefleme ve konumlandırma açısından daha iyi sonuçlar verdiğini çalışmalarıyla desteklemişlerdir ve bunu uluslararası bölümlendirme açısından gerekli olduğunu belirtmiştirler.

Hassan ve Craft $(2004,2005,2012)$ ve Hassan ve diğ. (2003) de hem makro hem de mikro değişkenlere dayalı UPB'nin hem bölümlendirme hem de yapılan bölümlendirmenin sonraki aşama olan konumlandırmayla ilişkilendirilmesindeki başarısını arttıracağını belirtmiştir. Hassan ve Craft (2004, 2005, 2012) ve Hassan ve diğ. (2003) her iki türden değişkenin bir arada kullanılarak yapılan bölümlendirmeyi hibrit/karma bölümlendirme olarak tanımlamışlardır. Bu bütünleşik yaklaşımda her iki türden değişken de bölümlendirme açısından göz önünde bulundurulduğundan, tüketici pazarlarının gerek küresel düzeyde gerekse ulusal düzeyde birtakım benzerlikler ve farklılıklar ve bu ikisinin değişik kombinasyonlarını içerebileceğini belirtmişlerdir. Hassan ve 
Craft $(2006,2012)$ ise makro ve mikro değişkenleri inceledikleri çalışmalarında, küresel pazarların genelinde benzer stratejiler uygulamayı isteyen firmalar açısından makro ve mikro değişkenlerin birlikte kullanımının daha iyi sonuç ürettiğini ancak farklılaşarak konumlandırma stratejisi uygulamak isteyen firmalar içinse, sadece mikro değişkenlerin daha iyi sonuç ürettiğini belirtmişlerdir. Gaston-Breton ve Martin Martin (2011) iki aşamalı UPB'yi diğer araştırmacılardan biraz daha farklı ele almış ve ilk olarak makro değişkenlere (pazar büyüklüğü ve büyüme oranı) dayalı olarak yaptığı analizle uluslararası pazar seçimi yapmıştır. Daha sonra, ikinci aşamada ise, mikro değişkenlere (kişisel ve sosyal değerler.) bağlı olarak seçilen ülkelerde uluslararası pazar bölümlendirmesi yapmıştır.

Tüketicilerin genel ve gözlemlenebilen değişkenlere göre bölümlendirilmesi temelde bazı sorunları da beraberinde getirmektedir. Örneğin, artan ve giderek birbirine yaklaşan tüketici gelirlerine dayanarak tüketicilerin benzer harcama eğilimlerinde olacağını belirtmek çok doğru sonuçlar üretmekten uzak olabilir. Çünkü özellikle UPB alanındaki çalışmalarda tüketiciler genel ve gözlemlenebilen değişkenlere göre değil, motivasyon gibi gözlemlenemeyen değişkenlere göre bölümlendirilmelidir, özellikle bu motivasyonların gerisinde yatan kültür etkeni büyük farklılıklar doğurabilmektedir. Bu nedenle, Kale ve Sudharshan (1987) tarafından ortaya atılan ve genel değişkenlere dayalı oluşturulan pazar bölümlerinin ekonomik ve diğer çevresel faktörler karşısında zamanla değişimini incelemek, ilgili pazar bölümlerinin sadece tanımlanabilirliğini ve ulaşılabilirliğini arttırabilir (Cannon ve Yaprak, 2011). Bunun dışında kültürel faktörleri göz önünde bulundurmadığı için özellikle UPB alanında eksik ve yanlış sonuçlar ortaya çıkabilir.

Kültürün tüketicilerin başta motivasyonları olmak üzere birçok davranışını etkileyen yapısı nedeniyle, kültürel çevrenin tüketici algısını, ihtiyaçlarını ve isteklerini etkilediği ve buna bağlı olarak da UPB çalışmalarında kültür ve kültürel çevrenin dikkate alınması gerektiğini vurgulanmıştır. Hatta bir adım daha ileri giderek, kültürel çevrenin değişimine ve kültürel çevrenin tüketici üzerindeki değişen etkisine dayalı olarak değişen, bir diğer ifadeyle dinamik, pazar bölümlendirmenin kültürler arası ve uluslararası pazar bölümlendirme açısından daha uygun olacağını ifade etmiştir (Cannon ve Yaprak, 2011).

\section{Sonuç ve Değerlendirmeler}

UPB firmalara dünya genelindeki benzer tüketicileri tanımlayıp, hedeflemelerine ve böylelikle ölçek ekonomisinden yararlanmalarına büyük katk1 sağlamaktadır. Küresel firmalar bu sayede daha düşük üretim, reklam ve dağıtım maliyetlerine sahip olmaktadır (Yip, 1995). Her ne kadar politik ve 
yasal birçok engel bulunsa da ve ülkeler arasında bu anlamda bir farkl1lık söz konusu olsa da, uluslararası pazarda başarılı olmak isteyen firmalar küresel tüketicilerin varlığını kabul etmeli ve pazar bölümlendirmelerinden başlayarak, tüm pazarlama faaliyetlerinin buna göre şekillendirmelidirler. Pazarlamanın başarısı tüketici değer, tutum ve davranışlarıyla psikolojik ve sosyolojik değişkenlere dayalı oluşturduğu pazar bölümlerinde uygulamaya koyduğu stratejilere bağlıdır. UPB'nin her geçen gün artan önemi küresel pazarların firmalar açısından öneminin artıyor olması veya pazarların giderek küreselleşmesi olduğu kadar, UPB'nin firmaların pazarlama performansını artıran önemli bir strateji olmasidır (Craft ve Hassan, 2006).

Hassan ve Craft'a $(2004,2012)$ göre, konumlandırmayla ilişkilendirilen veya bölümlendirme sonrası aşama olan konumlandırmanın, göz önünde bulundurulduğu UPB daha başarılı olacaktır. Bu nedenle UPB'ye temel olan değişkenlerin seçimi, büyük bir titizlikle ve bölümlendirmenin sonraki aşamalarını da dikkate alarak yapılmalıdır. UPB çalışmalarının küresel marka konumlandırma stratejileriyle yakından ilişkili olması, bu stratejilerin başarılarını arttıracaktır (Hassan ve Craft, 2004, 2005, 2012).

Son y1llarda ülkelerin kurumsal, sosyal, politik ve yasal olarak da birbirlerine yaklaştığını belirten çalışmalar, literatürde daha fazla yer almaya başlamıştır (örneğin, Griffith, 2010). Cannon ve Yaprak (2011) artan küreselleşmeyle ve küresel kültürdeki değişimle birlikte, UPB araştırmalarının nasıl değişeceğini düşünmemiz ve buna bağlı olarak daha çok kültürel değişkenlere odaklanmamız gerektiğini belirtmiştir. Mevcut pazar bölümlendirme değişkenleri, post modern tüketici özelliklerine uygun pazar bölümleri oluşturamamaktadır (Amine ve Smith, 2009). Bu nedenle özellikle UPB alanında post modern tüketicileri daha iyi gruplandıracak değişkenlerin geliştirilmesi ve UPB sürecinde yeni tüketici özelliklerine dikkat edilmesi UPB'nin başarısı ve etkinliği açısından büyük fayda sağlayacaktır.

UPB'nin firmaların uluslararası stratejilerindeki önemine rağmen bu çalışmaların etkinliğinin ölçülmesi, literatürde yeterince yer bulmamıştır. Halbuki, UPB çalışmalarının başarılarının ve etkinliklerinin değerlendirilmesi gerekmektedir. Bu amaçla, bölümlendirme etkinliği ölçeği geliştirilmiştir (Foedermayr ve Diamantopoulos, 2008a). UPB alanındaki çalışmalarının kendi etkinliklerini değerlendirmesi açısından bu ölçek önemli yere sahiptir.

UPB'nin artık demografik, psikolojik ve sosyolojik değişkenlere bağlı olarak yapılmaması gerekmektedir. UPB alanı son yıllarda büyük ilerlemeler kaydetmesine karşın, hali hazırda keşifsel yapısından kurtulamamıştır, gelecekteki çalışmaların daha güçlü, teoriye dayalı, modele dayalı ve gelişmiş istatistiksel teknikler kullanılarak yapılması, UPB alanın gelişimi ve ilerlemesi 
açısından son derece gereklidir (Steenkamp ve ter Hofstede, 2002). Benzer bir vurgu, Foedermayr ve Diamantopoulos (2008b) tarafindan da dile getirilmiş ve genel olarak pazar bölümlendirme çalışmalarının keşifsel yapıdan kurtulup, açıklayıcı bir yapıya sahip olması gerektiği belirtilmiştir. Ayrıca pazar bölümlerinin varlığının doğrulanması ve bu bölümlerin tutum ve davranışlarının tahmin edilmesi gerekmektedir. Modele dayalı UPB çalışmalarının sayısı son yıllarda artmakla birlikte, bu çalışmalar hem veri toplanmasında, hem çalışmanın yürütülmesinde hem de verilerin analizinde araştırmacıların, özellikle istatistiki açıdan, son derece donanımlı olmalarını gerektirmektedir. Ancak bununla birlikte, modele dayalı UPB çalışmaları, tüketici davranışı, pazarlama teorisi ve gelişmiş istatistiki yöntemleri birleştirerek çok daha ileri ve gelişmiş pazar bölümlendirmesi yapabilmektedir, ayrica bu modellerin bölümler için yüksek tahmin gücü de bulunmaktadır (Steenkamp ve ter Hofstede, 2002).

UPB alanındaki çalışmaların az olmasının en önemli nedenlerinden biri de çalışmaların uluslararası olması ve birden fazla ülkede yapılması gerekliliğidir. Son zamanlarda artan tüketici odaklı çalışmalar, UPB çalışmalarının tüketici bazında ve birçok ülkeyi ele alarak incelemesi ve keșifselden çok, tahmin edici modeller çerçevesinde değerlendirilmesi gerektiğini vurgulamasından dolayı, UPB çalışmalarının geleceği bir hayli zorlu görülmektedir. Pazar bölümlerini sabit olarak oluşturmak, UPB'nin kullanılabilirliğini azaltmaktadır (Steenkamp ve ter Hofstede, 2002). 


\section{KAYNAKÇA}

Adams, R. (2011). Fragmentation And Segmentation: Marketing Global Benefits. International Business \& Economics Research Journal, 10(9), 59-66.

Agarwal, J., Malhotra, N. K., \& Bolton, R. N. (2010). A Cross-National and Cross-Cultural Approach to Global Market Segmentation: An Application Using Consumers' Perceived Service Quality. Journal of International Marketing, 18(3), 18-40.

Agarwal, M. K. (2003). Developing Global Segments and Forecasting Market Shares: A Simultaneous Approach Using Survey Data. Journal of International Marketing, 11(4), 56-80.

Alden, D. L., Steenkamp, J.-B. E., \& Batra, R. (1999). Brand Positioning Through Advertising in Asia, North America, and Europe: The Role of Global Consumer Culture. The Journal of Marketing, 63(1), 75-87.

Amine, L. S., \& Smith, J. A. (2009). Challenges to Modern Consumer Segmentation in a Changing World: The Need for a Second Step. Multinational Business Review, 17(3), 71-99.

Arnett, J. (2002). The psychology of globalization. American Psychologist, 57(10), 774 783.

Aulakh, P., \& Kotabe, M. (1993). An assessment of theoretical and methodological development in international marketing: 1980-1990. Journal of International Marketing, 1(2), $5-28$.

Aurifeille, J.-M., Quester, P., Lockshin, L., \& Spawton, T. (2002). Global vs international involvement-based segmentation. International Marketing Review, 19(4), 369-386.

Baker, M. (2003). The marketing book (5 b.). Oxford: Butterworth-Heinemann.

Belvaux, B., \& Guibert, N. (2012). International segmentation: Towards a third path between global and national. International Journal of Market Research, 54(1), 111-127.

Bijmolt, T. H., Paas, L. J., \& Vermunt, J. K. (2004). Country and consumer segmentation: Multi-level latent class analysis of financial product ownership. International Journal of Research in Marketing, 21, 323-340.

Bolton, R. N., \& Myers, M. B. (2003). Price-Based Global Market Segmentation for Services. Journal of Marketing, 67, 108-128.

Brengman, M., Geuens, M., Weijters, B., Smith, S. M., \& Swinyard, W. R. (2005). Segmenting Internet shoppers based on their Web-usage-related lifestyle: a cross-cultural validation. Journal of Business Research, 58, 79- 88.

Broderick, A. J., Greenley, G. E., \& Mueller, R. D. (2007). The Behavioural Homogeneity Evaluation Framework: multi-level evaluations of consumer involvement in international segmentation. Journal of International Business Studies, 38, 746-763.

Bruning, E. R., Hu, M. Y., \& Hao, W. (. (2009). Cross-national segmentation: An application to the NAFTA airline passenger market. European Journal of Marketing, 43(11/12), 1498-1522.

Cannon, H. M., \& Yaprak, A. (2011). A dynamic framework for understanding crossnational segmentation. International Marketing Review, 28(3), 229-243. 
Carpenter, J., Moore, M., Doherty, A. M., \& Alexander, N. (2012). Acculturation to the global consumer culture: a generational cohort comparison. Journal of Strategic Marketing, 20(5), 411-423.

Christodoulides, G., Michaelidou, N., \& Siamagka, N. T. (2013). A typology of internet users based on comparative affective states: evidence from eight countries. European Journal of Marketing, 47(1/2), 153-173.

Cleveland, M., \& Laroche, M. (2007). Acculturation to the global consumer culture: Scale development and research paradigm. Journal of Business Research, 60(3), 249-259.

Cleveland, M., Papadopoulos, N., \& Laroche, M. (2011). Identity, demographics, and consumer behaviors: international market segmentation across product categories. International Marketing Review, 28(3), 244-266.

Craft, S. H. (2004). The International Consumer Market Segmentation Managerial DecisionMaking Process. SAM Advanced Management Journal, 69(3), 40-46.

Craft, S., \& Hassan, S. S. (2006). Global consumer market segmentation strategy decisions and managerial assessment of performance. Developments in Marketing Science, 29, 26-30.

Dickson, P. R., \& Ginter, J. L. (1987). Market Segmentation, Product Differentiation, and Marketing Strategy. Journal of Marketing, 51(2), 1-10.

Erez, M., \& Gati, E. (2004). A Dynamic, Multi-Level Model of Culture: From the Micro Level of the Individual to the Macro Level of a Global Culture. Applied Psychology, 53(4), 583-598.

Firat, A. F. (1997). Globalization of Fragmentation: A Framework for Understanding Contemporary Global Markets. Journal of International Marketing, 5(2).

Foedermayr, E. K., \& Diamantopoulos, A. (2008a). Exploring the Construct of Segmentation Effectiveness: Insights from International Companies and Experts. Journal of Strategic Marketing, 16(2), 129-156.

Foedermayr, E. K., \& Diamantopoulos, A. (2008b). Market Segmentation in Practice: Review of Empirical Studies, Methodological Assessment, and Agenda for Future Research. Journal of Strategic Marketing, 16(3), 223-265.

Foedermayr, E., Diamantopoulos, A., \& Sichtmann, C. (2009). Export segmentation effectiveness: index construction and link to export performance. Journal of Strategic Marketing, 17(1), 55-73.

Frank, R., Massy, W., \& Wind, Y. (1972). Market segmentation. Englewood Cliffs, NJ: Prentice-Hall.

Gaston-Breton, C., \& Martin Martin, O. (2011). International market selection and segmentation: a two-stage model. International Marketing Review, 28(3), 267-290.

Ger, G., \& Belk, R. W. (1996). I'd Like to Buy the World a Coke: Consumptionscapes of the "Less Affluent World". Journal of Consumer Policy, 19(3), 271-304.

Hassan, S. S., \& Craft, S. (2012). Examining world market segmentation and brand positioning strategies. Journal of Consumer Marketing, 29(5), 344-356.

Hassan, S. S., \& Craft, S. H. (2004). An Examination of Global Market Segmentation Bases and Strategic Positioning Decisions. International Business \& Economics Research Journal, 3(9), 79-84.

Hassan, S. S., \& Craft, S. H. (2005). Linking global market segmentation decisions with strategic positioning options. Journal of Consumer Marketing, 22(2), 81-89. 
Hassan, S. S., \& Katsanis, L. P. (1991). Identification of Global Consumer Segments: A Behavioral Framework. Journal of International Consumer Marketing, 3(2), 11-28.

Hassan, S. S., \& Katsanis, L. P. (1994). Global market segmentation and trends. E. Kaynak, \& S. S. Hassan içinde, Globalization of consumer markets: Structures and strategies (s. 47-63). New York: International Business Pres.

Hassan, S. S., Craft, S., \& Kortam, W. (2003). Understanding the new bases for global market segmentation. Journal of Consumer Marketing, 20(4/5), 446-462.

Helsen, K., Jedidi, K., \& DeSarbo, W. S. (1993). A New Approach to Country Segmentation Utilizing Multinational Diffusion Patterns. Journal of Marketing, 57, 60-71.

Jeannet, J. P., \& Hennessey, H. D. (1998). Global marketing strategies (4 b.). Boston: Houghton Mifflin.

Kahle, L. R. (1986). The nine nations of North America and the value basis of geographic segmentation. Journal of Marketing, 50, 37-47.

Kale, S. H., \& Sudharshan, D. (1987). A Strategic Approach to International Segmentation. International Marketing Review, 4(2), 60-70.

Kamakura, W. A., \& Novak, T. P. (1992). Value-system Segmentation: Exploring the Meaning of LOV. Journal of Consumer Research, 19(1), 119-132.

Ko, E., Kim, E., Taylor, C. R., Kim, K. H., \& Kang, I. J. (2007). Cross-national market segmentation in the fashion industry: A study of European, Korean, and US consumers. International Marketing Review, 24(5), 629-651.

Ko, E., Taylor, C. R., Sung, H., Lee, J., Wagner, U., Navarro, D. M.-C., et al. (2012). Global marketing segmentation usefulness in the sportswear industry. Journal of Business Research, $65,1565-1575$.

Kotler, P., \& Keller, K. (2006). Marketing management (12 b.). Upper Saddle River, NJ: Prentice Hall.

Levitt, T. (1983). The Globalization of Markets. Harvard Business Review, 61(3), 92-102.

Lim, H., \& Lee, H.-J. (2010). Development of consumer techno segmentation and its application to international markets. International Journal of Consumer Studies, 34, 87-95.

Malhotra, S., \& Papadopoulos, N. (2007). International market selection: an integrative review of empirical studies. Proceedings, Administrative Sciences Association of Canada, International Business Division. Ottawa, ON.

Nachum, L. (1994). The Choice of Variables for Segmentation of the International Market. International Marketing Review, 11(3), 54-67.

Papadopoulos, N., \& Martin Martin, O. (2011). International market selection and segmentation: perspectives and challenges. International Marketing Review, 28(2), 132-149.

Riefler, P., Diamantopoulos, A., \& Siguaw, J. A. (2012). Cosmopolitan consumers as a target group for segmentation. Journal of International Business Studies, 43, 285-305.

Rokeach, M. J. (1973). The nature of human values. New York: Free Press.

Sethi, S. P. (1971). Comparative cluster analysis for world markets. Journal of Marketing Research, 8, 348-354.

Shiu, E. C., \& Dawson, J. A. (2002). Cross-national consumer segmentation of Internet shopping for Britain and Taiwan. The Services Industries Journal, 22(10), 147-166.

Smith, W. (1956). Product differentiation and market segmentation as alternative marketing strategies. Journal of Marketing, 21, 3-8. 
Souiden, N. (2002). Segmenting the Arab markets on the basis of marketing stimuli. International Marketing Review, 19(6), 611-636.

Steenkamp, J.-B. E., \& ter Hofstede, F. (2002). International market segmentation: issues and perspectives. International Journal of Research in Marketing, 19, 185-213.

Steenkamp, J.-B. E., Batra, R., \& Alden, D. L. (2003). How perceived brand globalness creates brand value. Journal of International Business Studies, 34(1), 53-65.

ter Hofstede, F., Steenkamp, J.-B. E., \& Wedel, M. (1999). International Market Segmentation Based on Consumer-Product Relations. Journal of Marketing Research, 36(1), 1-17.

ter Hofstede, F., Wedel, M., \& Steenkamp, J.-B. E. (2002). Identifying Spatial Segments in International Markets. Marketing Science, 21(2), 160-177.

Walters, P. G. (1997). Global Market Segmentation: Methodologies and Challenges. Journal of Marketing Management, 13, 165-177.

Wedel, M., \& Kamakura, W. (2000). Market Segmentation: Conceptual and Methodological Foundations. Norwell, MA: Kluwer Academic Publishers.

Wind, Y., \& Douglas, S. P. (1972). International market segmentation. European Journal of Marketing, 6(1), 17-25.

Wind, Y., \& Douglas, S. P. (1981). International Portfolio Analysis and Strategy: The Challenge of the 80s. Journal of International Business Studies, 12, 69-82.

Yavas, U., Verhage, B. J., \& Green, R. T. (1992). Global Consumer Segmentation Versus Local Market Orientation: Empirical Findings. Management International Review, 32(3), 265272.

Yip, G. S. (1995). Total global strategy. Englewood Cliffs, NJ: Prentice Hall. 